\section{Species of Liriope Cultivated in the Southeastern United States}

\author{
Paul R. Fantz $z^{1,2}$
}

AdDitional index words. lilyturf, monkey grass, Convallariaceae, Haemodoraceae, Liliaceae, Ophiopogonaceae, Ruscaceae, morphology, ornamentals, ground covers, taxonomic key

SUMmARY. Species of Liviope Lour. are versatile, evergreen, grass-like perennials used in many landscaping situations. The industry commonly recognizes two species, $L$. muscari (Decne.) L.H. Bailey and L. spicata Lour. Additional species are poorly known in the green industry, and include misidentified species of Ophiopogon Ker-Gawl. A taxonomic treatment of liriopogons cultivated in the southeastern United States has been in progress for nearly 15 years. Plants bearing the names of L. kansuensis C.H. Wright belonged to the genus Ophiopogon. Plants bearing the name L.graminifolia Baker were misidentified as Ophiopogon sp. or belonged to L. spicata. One nursery had L. maireii, a species name lacking in plant name indices, and was excluded as a species. The names L. muscari and L. platyphylla F.T. Wang \& T. Tang linked recently as synonyms are segregated as two distinct species. Six species of Liviope are delineated and quantitatively described, with a taxonomic key to segregation presented. These species include L. exiliflora (L.H. Bailey) H.H. Hume, L. gigantea H.H. Hume, L. minor (Maxim.) Makino, L. muscari, L. platyphylla, and L. spicata.

S pecies of Liriope (Ruscaceae Spreng., formally assigned to Convallariaceae Horan., Haemodoraceae Arnott, Ophiopogonaceae Endl., or Liliaceae Juss.) are evergreen, grass-like perennials used in landscapes as casual groundcovers in small areas, entryways, or courtyards, as borders along paths, edging beds, driveways, or sidewalks, in rock gardens, along streams, around bases of trees or shrubs, in containers, and around pools (Sunset Editorial Staff, 1997; Tenenbaum et al., 1994). Plants grow in filtered sun to full shade, and are regarded as fairly drought tolerant for short periods (Huxley et al., 1992; Tenenbaum et al., 1994).

Salary and research support provided in part by Research Project NC0 6104 funded by the North Carolina Agricultural Research Service (NCARS; Raleigh, NC 27695-7643); additional funds in support of research provided by Taylor's Nursery, Inc. (Raleigh, NC) and publication funds provided by the North Carolina Association of Nurserymen.

Thanks go to Paul Lineberger, retired Superintendent, Horticultural Field Laboratory, Raleigh, and his staff for cultural assistance with the germplasm collection used in this study, to George Wilson, and to those individuals, nurseries, and botanical gardens that donated plants for research.

The use of nursery and trade names in this publication does not imply endorsement by NCARS of the nurseries or the products mentioned nor criticism of similar ones mentioned.

${ }^{1}$ Department of Horticultural Science, North Carolina State University, Raleigh, NC 27695-7609

${ }^{2}$ Corresponding author. E-mail: paul_fantz@ncsu.edu.
Species of Liriope are known commonly as lilyturfs (Fantz, 2008, Huxley et al., 1992, Sunset Editorial Staff 1997, Tenenbaum et al., 1994). Species of Liriope in the green industry marketed as aztec grass belong to Mondo grass is a name used occasionally for creeping species of Liriope, but is associated primarily with species of Ophiopogon. Also, monkey Liriope, but this name is applied to members of both genera (Fantz, 2008).

Two species are well known in the landscape-nursery industry, $L$. muscari and L. spicata (Huxley et al., 1992; Sunset Editorial Staff. 1997; Tenenbaum et al., 1994). Two names rarely encountered in the industry were L. kansuensis C.H. Wright and L. graminifolia Baker. Plants bearing these names belonged to the genus Ophiopogon, or some with the latter name were equivalent to L. spicata. Some gardens had begun adopting $L$. platyphylla (Wang and Tang, 1951) as a substitute name for $L$. muscari. I disagree, recognizing these as two distinct spethe genus Ophiopogon. (Fantz, 2008). grass is applied to creeping species of cies. This study recognizes six species of Liriope currently available. The objectives of this article are to provide an inventory of the cultivated species of Liriope found in the eastern United States, a key to their segregation and identification, an original quantitative botanical description based upon research data, and commentary on pertinent notes and observations.

\section{Materials and methods}

Germplasm of liriopogons cultivated in the United States following procedures described by Fantz (Fantz, 1993, 2008) were accumulated, grown together from 1990 to 2005 for morphological comparison and observation over the past decade, and vouchered. Morphological terminology used in the descriptions and in the taxonomic key follow terms as defined in Table 1. Commentary on the phytography (descriptive terminology of the morphology) of various organs was presented in a discussion of the liriopogon genera (Fantz, 2008). Plants were vouchered for deposit in herbaria, primarily for the North Carolina State University Herbarium, Raleigh (NCSC) and National Arboretum Herbarium, Washington, DC (NA). Additional specimens will be sent to herbaria at the Missouri Botanical Garden, St. Louis (MO), the University of Florida, Gainesville (FLAS), and Louisiana State University, Baton Rough (LSU). A dichotomous key is presented to assist in delineation, segregation, and identification of species of Liriope found in the green industry in the southeastern United States. Multiple traits were used for each couplet with contrasting characters provided. All collection numbers cited were vouchers collected by P.R. Fantz, and are a representative sample of the taxa described.

\section{Results and discussion}

Fantz (1993) provided a chronological, taxonomic history of liriopogons. Bailey (1929) recognized two species of Liriope, L. muscari and L. spicata, the two species recognized today in the green industry.

\begin{tabular}{llll}
\hline $\begin{array}{l}\text { Units } \\
\begin{array}{l}\text { To convert U.S. to SI, } \\
\text { multiply by }\end{array}\end{array}$ & U.S. unit & SI unit & $\begin{array}{l}\text { To convert SI to U.S., } \\
\text { multiply by }\end{array}$ \\
\hline 2.54 & inch(es) & $\mathrm{cm}$ & 0.3937 \\
25.4 & inch(es) & $\mathrm{mm}$ & 0.0394
\end{tabular}


Table 1. Terminology used in describing the morphology of liriopogons. Measurements used are in metric units $(1 \mathrm{~mm}=$ 0.0394 inches) and standard taxonomic format ( $x-y$ is common measurement range).

\section{Characteristics and definitions}

\section{General terms}

Bib: a daughter plant with a few leaves; trade marketing term for sale of individual, daughter, liriopogon plants.

Glabrous: lacking hairs; glabrate is nearly hairless.

Liriopogon: general term applied to grass-like plants of the genera Liriope and Ophiopogon.

Phytography: general term for descriptive terminology (morphology) of plants and their component parts.

Pubescent: hairs present.

\section{Plant structure}

Caespitose: plants expand outward radially from crown of subterranean stem in dense tufts forming a mound or cushion on the ground.

Caudex: a short, thickened, vertical, perennial, subterranean stem with daughter plants produced laterally from the caudex.

Fibrous: numerous, filamentous (threadlike) roots, $0.5-2 \mathrm{~mm}$ diameter

Fleshy: roots few, thickened, 2-4 mm diameter

Primary root: main root axis borne from the subterranean stem bearing lateral secondary roots.

Rhizome: thickened, subterranean, woody-like stem with inconspicuous nodes, leaves appressed, inconspicuous, deteriorating quickly leaving veins.

Rhizomatous: plant bears a subterranean stem (caudex) with propagative shoots (rhizomes) sent out that culminate in a daughter plant; often cited as stoloniferous in literature.

Secondary roots: lateral roots borne off of the primary root and typically smaller in diameter and shorter in length.

\section{Leaves}

Abaxial: lower surface, the side away from the axis.

Acuminate: a prolonged pointed apex, tapering concave curved.

Acute: a pointed apex, tapering straight.

Adaxial: upper surface, the side toward the axis.

Appressed: leaves lay flat against stem surface (on rhizomatous stems).

Maculate: spotted or blotchy patches on surface.

Pliable leaf: leaves easily bent or folded upon itself by man, exhibiting minimal damage.

Rigid leaf: leaves thick-textured, resist bending or folding upon itself by man, and typically tearing at folding point.

Inflorescences

Bract: modified leaf-like structure subtending a flower, borne at base of pedicel.

Branched rachis: rachis branching above, appearing panicle-like; panicle of dichasia.

Cockscomb: general term to a rachis expanding laterally and flattening near the apex.

Congested fascicles: fascicles borne close together with short rachis internodes.

Fasciation: general term referring to a cockscomb bearing two to several axes bearing flowers from the cockscomb apex.

Fascicle: clusters of flowers or fruit borne laterally from the rachis.

Foliar bract: elongated, leaf-like bract, borne early in season only at the lowest fascicles.

Hyaline: basal phlanges of leaves and bracts that are translucent.

Inflorescence: a flowering branch; also used herein for a fruiting branch.

Loose fascicles: fascicles spaced apart with long rachis internodes, particularly at lower to middle rachis nodes.

Pedicel: stalk of the flower or fruit, measured from the node to the flower base.

Peduncle: stalk of the inflorescence, measured from the base to the node bearing the first buds, flower or fruit.

Raceme: an elongated axis bearing pedicillate or stalked flowers.

Rachis: term for the portion of the inflorescence axis from which flowers and fruit are borne.

Translucent: almost transparent structure as in the hyaline areas of leaves

Flowers

Anther: pollen sac in a stamen borne at the apex of the filament.

Bud: an undeveloped flower.

Filament: stalk of the stamen.

Naviculate: surface bears a keel like a boat.

Ovary: expanded basal portion of pistil that bears the ovules; becomes fruit at maturity.

Perianth: general term that includes sepals and petals collectively, the floral envelope.

Perigone: fused perianth tube that narrows abruptly into a prolonged basal projection.

Petals: the inner whorl of the perianth.

Pistil: female reproductive organ of a flower, comprised of a basal ovary, a style, and the terminal stigma.

Sepals: the outer whorl of the perianth.

Stamen: male reproductive organ in a flower, comprised of a filament and an anther.

Style: narrow portion of pistil connecting stigma to the ovary. 
Hume (1961) added L. exiliflora, L. gigantea, and L. graminifolia. I agree with Hume that $L$. exiliflora and $L$. gigantea are distinct species as he had proposed (Hume, 1961). However, the industry typically lumps them with $L$. muscari, or the former sometimes with L. spicata. Specimens marketed as L. graminifolia are a mixture of L. spicata or a species of Ophiopogon.

Ophiopogon muscari Decne. was transferred to Liriope as L. muscari (Bailey, 1929). Bailey's name was rejected (Wang and Tang, 1951) and the name $L$. platyphylla was proposed for this cultivated species. Liriope platyphylla was accepted in a flora with L. muscari cited in synonymy (Ohwi, 1953). In the 1990s, several U.S. botanical gardens changed plant labels from a cultivar of $L$. muscari to a cultivar of $L$. platyphylla, accepting the prior taxonomic treatment (Wang and Tang, 1951). However, Bailey's transfer was recognized as legitimate, with $L$. platyphylla cited as a synonym of L. muscari (Hara, 1984; Huxley et al., 1992). Thus, these two names have been linked together for half a century. Which is the correct name and which name is the synonym? The U.S. trade has never caught up to this proposed name change, maintaining the name $L$. muscari on plants sold.

Liriope muscari and L. platyphylla are regarded herein as two distinct species! Plants bearing the name $L$. platyphylla originating from China or European nurseries (who obtained them from China) are very distinct from cultivated selections of U.S. plants known as L. muscari. Letters written by the author over several years requested the opportunity to examine the type cited by Wang and Tang (1951) and deposited in a Chinese herbarium, but a reply was never received. G. Wilson, a departmental colleague and former President of the American Society for Horticultural Science visited the herbarium during a trip to China. The curator showed Wilson my letter(s) and allowed him to photograph several herbarium specimens of $L$. platyphylla, but the type was not included. None of these specimens were equivalent to $L$. muscari, but represent a separate species. Therefore, these two names should not be linked together in synonymy, and are treated herein as distinct.

There are six species of Liriope available in the nursery and landscape industry in the southeastern United
States. A taxonomic key to species of Liriope found cultivated is presented in Table 2. Each species is arranged alphabetically with an original botanical description by the author, followed by observational notes and comments. Within the botanical descriptions, the words leaves, inflorescence, flowers, and fruit are boldfaced to allow readers quick access to descriptions of those structures.

\section{Species of cultivated liriope.}

LiRIOPE EXILIFLORA. Plants rhizomatous; caudex 3 to $5 \mathrm{~cm}$ long, 1.5 to $2.5 \mathrm{~cm}$ wide, vertical orientation in soil; rhizomes 12 to $24 \mathrm{~cm}$ long, rhizomatous leaves thin membranous, 2 to $7 \mathrm{~mm}$ diameter, 3 to 4.5 $\mathrm{cm}$ long, 3 to $5 \mathrm{~mm}$ wide, tissue deteriorating, leaving veins as elongate, stiff bristles; roots fibrous, primary roots 5.5 to $14 \mathrm{~cm}$ long, 1 to $2 \mathrm{~mm}$ diameter, secondary roots sparsely branched, 2 to $6 \mathrm{~cm}$ long, about $0.5 \mathrm{~mm}$ wide. Leaves green to pale green, ascending-arching, pliable (19-22) 30 to $44.5 \mathrm{~cm}$ long, width type is medium to broad, 6 to $12 \mathrm{~mm}$ wide, bluntly acute, serrulate, basal hyaline 2 to $4 \mathrm{~mm}$ wide; veins 11 to 15 , slightly raised above, conspicuously raised below, five to eight veins

Table 2. Key to species of cultivated liriope

la. Inflorescence rachis 1 to $4 \mathrm{~cm}$ long; fascicles 4 to 15 ; outer bracts narrowly triangular with hyaline wings, 0.7 to $1 \mathrm{~mm}$ wide near apex, gradually expanding to $4 \mathrm{~mm}$ wide basally; peduncles 3.5 to $15 \mathrm{~cm}$ long; style 3 to $4 \mathrm{~mm}$ long, slightly exceeding anthers; leaves 2 to $7 \mathrm{~mm}$ wide.

2a. Flowers pale lilac, $8 \mathrm{~mm}$ diameter, 3 to 6 per fascicle; perianth tube $1 \mathrm{~mm}$ long; filaments pale whitish; style $3 \mathrm{~mm}$ long, pale whitish; fascicles 8 to 15 ; peduncle 2 to $3 \mathrm{~mm}$ wide; rachis 2.5 to $4 \mathrm{~mm}$ long; leaves 4 to $6 \mathrm{~mm}$ wide, 19 to $28 \mathrm{~cm}$ long. L. spicata

2b. Flowers violet, 10 to $12 \mathrm{~mm}$ diameter, 1 to 3 per fascicle; perianth tube $2 \mathrm{~mm}$ long; filaments dark purple; style $4 \mathrm{~mm}$ long, purplish with pale whitish apex; fascicles 4 to 5 ; peduncle $1 \mathrm{~mm}$ wide; rachis 1 to $2.5 \mathrm{~cm}$ long; leaves 2 to $4 \mathrm{~mm}$ wide, 7 to $15 \mathrm{~cm}$ long......

\section{L. minor}

1b. Inflorescence rachis 5 to $24 \mathrm{~cm}$ long; fascicles 25 to 80 ; outer bracts linear, $0.5 \mathrm{~mm}$ wide near apex, with abrupt, hyaline, ovate, wings borne basally, to $2 \mathrm{~mm}$ wide; peduncle 15 to $30 \mathrm{~cm}$ long; style 1.5 to $2.5 \mathrm{~mm}$, subequal to slightly less than height of anthers; leaves 6 to $23 \mathrm{~mm}$ wide.

3a. Leaves stiff, somewhat rigid, thick-textured, 60 to $80 \mathrm{~cm}$ long; flowers 11 to $13 \mathrm{~mm}$ diameter; perianth lobes 5 to $6 \mathrm{~mm}$ long; pedicels 4 to $6 \mathrm{~mm}$ long; fruit obovoid

L. gigantea

3b. Leaves pliable to somewhat stiff, easily bent, thin-textured, 15 to $45 \mathrm{~cm}$ long; flowers 7 to $11 \mathrm{~mm}$ diameter; perianth lobes 3.5 to $5 \mathrm{~mm}$ long; pedicels 2 to $4 \mathrm{~mm}$ long; fruit globoid.

4a. Rachis $23.5 \mathrm{~cm}$, about $3 / 4$ to $4 / 5$ peduncle length; fascicles 60 to 80 ; perianth tube 1 to $1.2 \mathrm{~mm}$ long; anthers 1.6 to $1.8 \mathrm{~mm}$ long; outer bracts obovate-elliptic, hyaline wings to near apex; stigma $\approx 0.7 \mathrm{~mm}$ long; flowers lavender

\section{L. platyphylla}

4b. Rachis 5 to $11 \mathrm{~cm}$ long, about $\mathrm{l} / 3$ to $\mathrm{l} / 2$ peduncle length; fascicles 35 to 50 ; perianth tube seemingly lacking to $1 \mathrm{~mm}$ long; anthers 1.4 to $1.6 \mathrm{~mm}$ long; outer bracts linear with abrupt, ovate, hyaline wings basally; stigma about $0.4 \mathrm{~mm}$ long; flowers violaceus to bluish-violet.

5a. Perianth tube distinct, 0.7 to $1 \mathrm{~mm}$ long; filaments 1.8 to $2 \mathrm{~mm}$ long; rachis open, lowermost internodes 5 to $14 \mathrm{~mm}$ long; style shorter than anthers by 0.5 to $1 \mathrm{~mm}$; rhizomatous; flowers bluish-violet

5b. Perianth tube inconspicuous, about 0.1 to $0.4 \mathrm{~mm}$ long; filaments 1.2 to $1.5 \mathrm{~mm}$ long; rachis crowded, lowermost internodes 4 to $6 \mathrm{~mm}$ long; style subequal anthers to shorter by about $0.5 \mathrm{~mm}$; caespitose; flowers violaceus.

L. muscari 
between midrib and margin; stomates numerous, conspicuous, grayishmaculate between veins. Inflorescence (17) 24 to $29 \mathrm{~cm}$ long, apex blunt with fascicle, flowers loosely arranged; peduncle green, angularterete, striate, $(9-13) 18.5$ to $28 \mathrm{~cm}$ long, 2 to $3 \mathrm{~mm}$ wide; rachis bluishviolet tinged whitish, (7) 9 to $12 \mathrm{~cm}$ long, to $1 \mathrm{~mm}$ wide; lowermost internode (5) 9 to $14 \mathrm{~mm}$ long, others 2 to $9 \mathrm{~mm}$ long; fascicles (18) 30 to 45 ; pedicels 3 to $5 \mathrm{~mm}$ long. Outer bract ovate phlange basally, abruptly linear apically, acute, 3 to $5 \mathrm{~mm}$ long, 1 to 2 $\mathrm{mm}$ wide; inner bracts membranous, ovate, 2 to $2.5 \mathrm{~mm}$ long, $\mathrm{l}$ to $1.5 \mathrm{~mm}$ wide; buds purplish. Flowers bluishviolet with perianth lobes bearing a thin white rim marginally; perianth tube 0.7 to $1 \mathrm{~mm}$ long, lobes $4 \mathrm{~mm}$ long, calyx lobes oblong, $2 \mathrm{~mm}$ wide, corolla lobes elliptic oblong, 2.5 to 3 $\mathrm{mm}$ wide. Filaments purple basally to whitish apically, 1.8 to $2 \mathrm{~mm}$ long; anthers yellow, 1.4 to $1.7 \mathrm{~mm}$ long, 0.6 to $0.8 \mathrm{~mm}$ wide. Ovary dark purple, $1.5 \mathrm{~mm}$ diameter; style 1.8 to $2 \mathrm{~mm}$ long, strongly falcate, shorter than anthers by 0.5 to 1 $\mathrm{mm}$. Fruit greenish becoming black, 6 to $8 \mathrm{~mm}$ diameter, one to two (4) per fascicle; seeds brown, globoid, 4.5 to $5 \mathrm{~mm}$ diameter.

Representative vouchers: 4488, 5127, 5139, 5198, 5204, 5239, $5464,5528,5605,5622,5751$, 5806, 6021, 6058, 6124, 6130, 6283,6343 .

Observations: Bailey (1929) described this taxon as a variety of $L$. muscari. Hume (1961) elevated the taxon to the rank of species forty years ago. However, the industry does not recognize this species or its name. I agree with Hume that it is a distinct species from L. muscari. In my opinion, this is the most commonly encountered Liriope in the landscape.

Leaves are intermediate in width between $L$. spicata and L. muscari, the two species under whose name this species typically is marketed and confused. Plants spaced apart will maintain a clumping effect for a couple of years, but will gradually fill in and present a lush carpet of green over the ground. It is not as aggressive or as invasive as L. spicata, but it will colonize an area. It will not maintain separate clumps as selections of L. muscari.
Flowers occur from mid-June through August. Flowers are purplish up close, but appear lighter in color to humans from a distance who have described them as bluish. This is from the eye observing the whitish rachis contrasting with the adjacent purple flowers, thus, the overall blending effect is a lighter pigmentation hue observed. In addition, the perianth lacks pigmentation at its margin, adding to the softer hue effect on the flowers.

Fruit occur from August and may persist through to the following May. Fruiting is medium to very abundant and persistent in this species. Thus, the cluster of black, conspicuous fruit adds to the winter ornamental value. Also, it has served as a faster propagation source than divisions for nurserymen, increasing their marketing stock.

Liriope exiliflora is very common in the landscape. This species is confused more commonly with $L$. muscari than L. spicata, as the inflorescences overtop the leaves and the flowers have a darker pigmentation, similar to L. muscari.

A good field observation is to use your hands to separate the leaves in a Liriope patch from above. It will be easy to observe patches of bare soil between bibs within the "clump" of L. exiliflora because of its rhizomatous habit. The bibs will be close together in caespitose L. muscari, making patches of bare soil more obscured or hidden. During the winter months, the abundant fruit set generally indicates $L$. exiliflora, as fruit commonly abort in L. muscari, leaving pedicellate racemes lacking, or bearing very few fruit.

LiRIOPE GIGANTEA Plants caespitose, forming dense clumps 35 to $75 \mathrm{~cm}$ tall; roots numerous from rhizome crown, 6 to $13 \mathrm{~cm}$ long, 0.4 to $0.8(1.0) \mathrm{mm}$ diameter, secondary rootlets 2 to 8 (20) $\mathrm{mm}$ long; storage organs ellipsoidal, 8 to $15 \mathrm{~mm}$ long, 5 to $7 \mathrm{~mm}$ diameter; rhizomatous stems lacking. Leaves deep green, stiff, erect to weakly arching, (17) 30 to $70 \mathrm{~cm}$ long, width type is wide, (8) 12 to $16 \mathrm{~mm}$ wide, margin entire, serrulate apically, veins 9 to 17 , five to nine per side. Inflorescences borne among leaves, 27 to $42 \mathrm{~cm}$ long; peduncles striate, quadrangular-terete, green becoming purplish apically, 21 to $26.5 \mathrm{~cm}$ long, to $3 \mathrm{~mm}$ wide; rachis striate-terete, (5) 9 to $17 \mathrm{~cm}$ long; fascicles 35 to 40 , internodes 6 to $14 \mathrm{~mm}$ long, buds liliaceous, $4 \times 3$ $\mathrm{mm}$; bracts acicular, $6 \mathrm{~mm}$ long $\times 0.4$ to $0.5 \mathrm{~mm}$ wide long, base ovate, 1 to $1.3 \mathrm{~mm}$ wide; bracteoles ovate, acute, 1.5 to $3 \mathrm{~mm}$ long. Flowers bluish to dark purplish with whitish margins, (1) 3 to 6 flowers per fascicle, 11 to 13 $\mathrm{mm}$ diameter; pedicels subquadrangular, white with purple maculation to purplish, 4 to $6 \mathrm{~mm}$ long; perigone to $1 \mathrm{~mm}$. Perianth tube lacking, lobes oblong, obtuse, recurved apically, (4) 5 to $6 \mathrm{~mm}$ long; calyx lobes $2.5 \mathrm{~mm}$ wide; corolla lobes $3 \mathrm{~mm}$ wide. Filaments purplish basally, white apically, 1.8 to $2.5 \mathrm{~mm}$ long; anthers yellow, 1.8 to $2 \mathrm{~mm}$ long, 0.6 to $0.8 \mathrm{~mm}$ wide. Ovary bluish-purple, six-lobed, about 1.5 to $2 \mathrm{~mm}$ diameter; style white, incurved-falcate, 1.8 to $2 \mathrm{~mm}$ long, exceeding anthers by 0.5 to 1.0 $\mathrm{mm}$. Fruit sparse, one to two per pedicel, black, subglobose, 6 to $8 \mathrm{~mm}$ diameter Seeds brownish, 5 to $6 \mathrm{~mm}$ diameter, subglobose.

Representative vouchers: 5171, $5409,5417,5509,5808,5821$, 6090, 6169, 6238, 6291, 6331.

Observations: Blooming occurs from mid-July through September. The fruit will swell in mid-September and persist through winter to February. The leaves are stiff, mostly erect with some spreading apically, but not becoming arched back and pointed downward toward the ground as observed in most species of liriopogons. The leaves are the longest and the most elegant green of liriopogons used in the landscape. This is the only species observed that will produce orangish pigmentation in the hyaline area just below the soil level in the summer.

Plants commonly are marketed as L. muscari 'Evergreen Giant' or 'Variegated Evergreen Giant'. 'Evergreen Giant' is a cultivar of this species. However, examination of the flowers of 'Variegated Evergreen Giant' will indicate that it is a misidentified species of Ophiopogon, and not a Liriope.

LIRIOPE MINOR. Plants forming mounds 12 to $15 \mathrm{~cm}$ tall, rhizomatous to form daughter plants apically; primary roots numerous, descending, fibrous, 2 to $10 \mathrm{~cm}$ long and 1.0 to $1.2 \mathrm{~mm}$ diameter, lateral rootlets spreading to $1.5 \mathrm{~cm}$ long; rhizomes 2 to $4 \mathrm{~cm}$ long, $2 \mathrm{~mm}$ diameter, 
bearing leaves appressed hyaline to thick-membranous, 2.5 to $7 \mathrm{~mm}$ long, disintegrating with age to appear as fibrous awns. Leaves 12 to 20 per bib, (55) 7.5 to $15.0 \mathrm{~cm}$ long, width is narrow to mini type, (1) 2 to $4 \mathrm{~mm}$ wide, glaucous abaxially between veins, lateral veins 3 to 5 , one to three per side, basal margins with flanges hyaline, membranous, 3 to $5 \mathrm{~mm}$ long, to $3 \mathrm{~mm}$ wide per side. Inflorescences short, borne amongst leaves, 5.0 to $8.5 \mathrm{~cm}$ long; peduncles lilac to purplish, 3.5 to $6.5 \mathrm{~cm}$ long, to $1 \mathrm{~mm}$ wide, laterally compressed with a thin wing on each side; rachis green tinged purplish, 1 to $2.5 \mathrm{~cm}$ long, internodes 7 to $9 \mathrm{~mm}$ long, fascicles three to six; buds lavenderpurplish, 4 to $6 \mathrm{~mm}$ long; bracts navicular, lanceolate, 4 to $5 \mathrm{~mm}$ long, $1 \mathrm{~mm}$ wide. Flowers lavender to purplish, one to three per fascicle, 10 to $12 \mathrm{~mm}$ diameter; pedicels 1 to $2 \mathrm{~mm}$ long, perigone pale whitish, 1 to $1.5 \mathrm{~mm}$ long, becoming campanulate apically. Perianth lobes $5 \mathrm{~mm}$ long, obtuse; calyx lobes elliptic, convex medially, 1.5 to $2.5 \mathrm{~mm}$ wide; corolla lobes obovate-elliptic, 2.5 to $3.0 \mathrm{~mm}$ wide. Stamens zygomorphic; filaments purplish, $2 \mathrm{~mm}$; anthers yellow, 1.6 to $1.8 \mathrm{~mm}$ long, 0.6 to $0.7 \mathrm{~mm}$ wide. Ovary 0.7 to $0.8 \mathrm{~mm}$ long; style obloid-falcate, purple with whitish apex, 3 to $4 \mathrm{~mm}$ long, exceeding anthers by $1 \mathrm{~mm}$. Fruit green as juvenile, aborting.

Representative vouchers: 5415, 5426, 5472, 5752, 6141.

Observations: This is a rare species in the green industry, found in limited botanic gardens labeled as a cultivar of Liriope or Ophiopogon japonicus. The plant generally will spread vegetatively with distant daughter plants. Flowering is rare, as populations were observed to produce flowers only four times in over a decade (1993, 1996, 2002, and 2006). Even then, only a few bibs produced an inflorescence. Of two populations transplanted to my yard 5 years ago, only one had bibs that produced blooms for the first time in 2006. Flowers appeared from late June through July. Fruit typically aborted before maturing in each of these blooming seasons.

LIRIOPE MUSCARI (SYN. Ophiopogon muscari DescN.). Plants caespitose forming tufted clumps, 15 to $30 \mathrm{~cm}$ tall. Leaves green, 20 to $39 \mathrm{~cm}$ long, width type is typically broad to slightly wide, 8 to 16 (23) $\mathrm{mm}$ wide, margin minutely serrate, veins 13 to 17 , six to eight per side, minute teeth on some veins. Inflorescences 20 to $30 \mathrm{~cm}$ long; peduncles green becoming purplishbrown/black to purple, 13 to $18 \mathrm{~cm}$ long, 3 to $6 \mathrm{~mm}$ wide; rachis 6 to 12 $\mathrm{cm}$ long, purplish, 3 to $4 \mathrm{~mm}$ wide, crowded, rarely branched, apex broad acute, occasionally expanding to form a cockscomb, or fasciated with short erect branches; bracts ovate-navicular, falcate, 3 to $4 \mathrm{~mm}$ long, 0.3 to 2 $\mathrm{mm}$ wide basally; foliar bracts 7 to 11 mm long; pedicels 2 to $4 \mathrm{~mm}$. Flowers violaceus to purple, or white; buds violet; tube inconspicuous, 0.1 to 0.4 $\mathrm{mm}$ long, lobes 4 to $4.5 \mathrm{~mm}$ long; sepals $2 \mathrm{~mm}$ wide; petals $3 \mathrm{~mm}$ wide. Filaments purple, $2 \mathrm{~mm}$ long; anthers yellow, $1.5 \mathrm{~mm}$ long, 0.5 to $0.6 \mathrm{~mm}$ wide. Ovary $2 \mathrm{~mm}$ long; style subequal filaments, shorter by 0.1 to 0.5 $\mathrm{mm}, 2 \mathrm{~mm}$ long. Fruit sparse, commonly aborting, globose, black, 3 to $4 \mathrm{~mm}$ diameter Seeds brownish, globose, 2.5 to $3.5 \mathrm{~mm}$ diameter.

Representative vouchers: 4359 , $5002,5053,5202,5324,5361$, $5383,5788,5849,5867,5959$, 5963, 5976, 6258, 6281.

Observations: Liriope muscari is an excellent landscape plant for edging beds, massing, and maintaining its location, as the species is caespitose. Daughter plants are produced from the upper portion of the caudex, forming a clumping mound that expands outward from its planting. It is commonly confused with $L$. exiliflora, but one can reach down into the clump from above with one's hands to separate the bibs. It will be difficult to observe bare soil patches between bibs. During the winter, fruit is commonly aborted, leaving naked, pedicellate inflorescences, or with few, sparse, scattered fruit.

This is the only species with inflorescence variations that have lead to distinct cultivar selections. Sometimes the rachis forms a cockscomb, flattening apically like an expanding fan to increase surface area for more buds and flowers. In addition, some inflorescences fasciate from the cockscomb apex, forming one or more apically, erect flowering branches. Also, this is the only species in which the inflorescence will exhibit lateral branching ('Christmas Tree'), but buds produced on lateral branches rarely open into a flower. Even then, the perianth opens only slightly. Variegated leaf forms will occur. Variegation may be reduced to a band at the leaf margin, golden yellow in juvenile leaves that fades in hue as leaves mature. Or, the variegation may occur in several longitudinal bands of green and yellow. Rarely, leaves will produce a transverse band of yellow. In a few selections, leaves are greenish-yellow throughout.

LIRIOPE PLATYPHYLLA. Plants caespitose, forming tufted clumps, seven to 15 leaves per bib; rhizomatous stems lacking. Leaves erect, slightly stiff, weakly arching above, 25 to $42 \mathrm{~cm}$ long, width type is broad, 8 to $13 \mathrm{~mm}$ wide, veins six to nine per side; margin hyaline basally, hyaline 1 to $2 \mathrm{~cm}$ long, 2 to $4 \mathrm{~mm}$ wide. Inflorescences overtopping leaves to about twice leaf height, 55 to $60 \mathrm{~cm}$ long; peduncles elongated, green, 32 to $38 \mathrm{~cm}$ long, 3 to $4 \mathrm{~mm}$ diameter; rachis green becoming whitish apically, 18 to $24 \mathrm{~cm}$ long, lowermost internodes 7 to $11 \mathrm{~mm}$ long; fascicles 60 to 80 , dense in middle of rachis; bracts $5 \mathrm{~mm}$ long, ovate, cuspidate with $3 \mathrm{~mm}$ long awn, bracteoles 3 $\mathrm{mm}$ long, obtuse, awnless, $2 \mathrm{~mm}$ wide. Flowers lavender to purple, erect, 7 to $9 \mathrm{~mm}$ diameter; four to eight flowers per fascicle; pedicels lavender, 1 to $2 \mathrm{~mm}$ long in flower, 2 to $3 \mathrm{~mm}$ long in fruit. Perianth tube 1.0 to $1.2 \mathrm{~mm}$ long, about $1.5 \mathrm{~mm}$ wide at throat, lobes 3.5 to $4 \mathrm{~mm}$ long; sepals 1.7 to $2 \mathrm{~mm}$ wide; petals 2 to $2.5 \mathrm{~mm}$ wide, obtuse. Stamens zygomorphic; filaments lavender, 2 $\mathrm{mm}$ long, anthers yellow, 1.6 to 1.8 $\mathrm{mm}$ long $\times 0.7$ to $0.8 \mathrm{~mm}$ wide. Ovary white speckled lavender, 0.7 to $0.8 \mathrm{~mm}$ long; style 1.7 to $2.0 \mathrm{~mm}$ long, thick, shorter stamens by $1 \mathrm{~mm}$; stigma about $0.7 \mathrm{~mm}$ diameter. Fruit black, globular, $6 \mathrm{~mm}$ diameter; seeds $5 \mathrm{~mm}$ diameter.

Representative vouchers: 5262 , 5398, 5463, 5489, 5779, 5861, 5899, 6111, 6135, 6231, 6263, 6378 .

Observations: This is a distinct species from L. muscari, yet the names are linked in the recent literature as noted in the previous discussion. In my opinion, these names should not be synonymous.

Liriope platyphylla is the most ornamental species in the flowering 
state, and should be used more frequently in the landscape. The inflorescences overtop the leaves much higher than L. muscari, bearing more fascicles of flowers than any other species. However, fruiting pedicels will bear dried, persistent, perianth members, which is less desirable as an ornamental trait when fruit typically abort. Rabbits continually ate the leaves of this species in research beds, ignoring L. muscari and other species, which exhibited infrequent feeding.

LIRIOPE SPICATA (SYN. L. GRAMINIFOLIA). Plants rhizomatous with many daughter plants forming a green carpet 15 to $21 \mathrm{~cm}$ tall; primary roots fibrous, descending, 5 to $13 \mathrm{~cm}$ long, 0.7 to $1.2 \mathrm{~mm}$ diameter, rootlets numerous, spreading, sparsely branched, 1 to $3 \mathrm{~cm}$ long, 0.2 to $0.6 \mathrm{~mm}$ diameter; rhizomatous stems three to six per bib, elongate, bear apigmented appressed leaves, 13 to $19 \mathrm{~cm}$ long, 3 to $4 \mathrm{~mm}$ diameter. Leaves green, thin, erect to weakly arching, (6) 10 to $26 \mathrm{~cm}$ long, width type is mini, (2) 4 to $6 \mathrm{~mm}$ wide, margin serrulate, veins five to nine, three to five per side, basal hyaline flange 1 to $2 \mathrm{~cm}$ long, 2 to $3 \mathrm{~mm}$ wide. Inflorescences 12 to $17.5 \mathrm{~cm}$ long; peduncles pale green to green with purplish base, compressed angular-terete, 9.5 to $14 \mathrm{~cm}$ long, 2 to 3 $\mathrm{mm}$ diameter; rachis 2.5 to $4 \mathrm{~cm}$ long, pale green to pale liliaceous; fascicles eight to 15 , open-loose, internodes 4 to $7 \mathrm{~mm}$ long, lowermost fascicle 12 to $40 \mathrm{~mm}$ below others; pedicels 2 to $3 \mathrm{~mm}$ long. Bracts 3 to $5 \mathrm{~mm}$ long, narrow triangular with hyaline wings to near apex, 0.7 to $1 \mathrm{~mm}$ wide, to 4 $\mathrm{mm}$ wide at base with wings; foliar bracts green, 2 to $3.5 \mathrm{~cm}$ long, 0.5 to $0.9 \mathrm{~mm}$ wide. Flowers pale lilac, lavender to pinkish, erect, six per fascicle; buds pinkish to light lavender, $5 \mathrm{~mm}$ long. Perianth tube about $1 \mathrm{~mm}$, lobes $4 \mathrm{~mm}$ long, obtuse, sepal lobes 1.5 to $2 \mathrm{~mm}$ wide, reflexed at apex; petal lobes 2.5 to $3 \mathrm{~mm}$ wide. Filaments white, $2 \mathrm{~mm}$ long; anthers yellow, 1.5 to $2 \mathrm{~mm}$ long, 0.5 to 0.6 $\mathrm{mm}$ wide. Ovary $2 \mathrm{~mm}$ long, style white, falcate, $3 \mathrm{~mm}$ long; slightly exceeding anthers, stigma terminal. Fruit globular, green becoming brown then black at maturity, 4.5 to $5 \mathrm{~mm}$ diameter. Seeds globloid, 4.5 $\mathrm{mm}$ diameter.

Representative vouchers: 4402, 4499, 5061，5155，5157，5624, 5906, 5971, 5980, 6074, 6107, 6334.

Observations: Any creeping plants with narrower leaves identified as Liriope are marketed under the name $L$. spicata, or sometimes as $L$. graminifolia. The name L. graminifolia is noted as a synonym of $L$. spicata by The International Plant Names Index (IPNI; Royal Botanical Garden, Kew; 2007). Plants of this species in the trade are misidentified commonly and are marketed as an Ophiopogon under the names O. japonicus, or infrequently as $O$. planiscapus.

Liriope spicata is aggressive and invasive with age. It is a great plant used on banks and areas to prevent soil erosion. Inflorescences are short, borne among the leaves, and the inconspicuous flowers are pale in hues; thus, are nonornamental. Flowers often attracted flies and gnats, but I was unable to detect any floral odor. During the colder months, the leaves lay down and the persistent fruit are visible.

\section{Excluded Liriope taxa}

LIRIOPE KANSUSENSIS. Plants bearing this name are encountered infrequently in the trade. All of these plants belonged to Ophiopogon. Lir iope kansuensis is reported as a synonym of $O$. kansuensis Batalin (Royal Botanical Garden, Kew, 2007). Representative vouchers: 5762, 5870, 6113.
LIRIOPE MAIREII. This name, found in one nursery, is lacking in the modern international index of published names (Royal Botanical Garden, Kew, 2007). The plant bearing this name was a member of L. exiliflora. Representative voucher: 6900 .

\section{Literature cited}

Bailey, L.H. 1929. The case of Ophiopogon and Liriope. Gentes Herbarium 2:3-37.

Fantz, P.R. 1993. Taxonomic problems in cultivated liriopogons. HortTechnology 3:146-150.

Fantz, P.R. 2008. Macrophytography of cultivated liriopogons and genera delineation. HortTechnology 18:334-342.

Hara, H. 1984. Comments on East Asiatic plants (13). J. Jpn. Bot. 59:33-39.

Hume, H.H. 1961. The Opbiopogon-Liriope complex. Baileya 9:134-158.

Huxley, A., M. Griffiths, and L. Margot (eds.). 1992. The new Royal Horticultural Society dictionary of gardening. Macmillan, London.

Ohwi, J. 1953. Flora of Japan. (English translation). 1965. F.G. Meyer and E.H. Walker (eds.). Smithsonian Institution, Washington, DC.

Royal Botanical Garden, Kew. 2005. IPNI, The International Plant Names Index. Liriope. 14 May 2007. http://www. ipni.org/ipni/plantnamesearchpage.do $>$.

Sunset Editorial Staff. 1997. Sunset national garden book. Sunset Books, Menlo Park, CA.

Tenenbaum, F., R. Buchanan, and R. Holmes (eds.). 1994. Taylor's master guide to gardening. Houghton Mifflin, New York.

Wang, F.T. and T. Tang. 1951. A new Liriope in cultivation but hitherto confused with a key to species of the genus. Acta Phytotaxonomica Sinica 1(4):331334. 